\title{
The Role of Extracellular Vesicles in the Pathogenesis, Diagnosis, and Treatment of Osteoarthritis
}

\author{
Jianjing Lin ${ }^{1,2}\left(\mathbb{D}\right.$, Li Wang $^{3}$, Jianhao Lin ${ }^{1,2}$ and Qiang Liu ${ }^{1,2, *(\mathbb{C}}$ \\ 1 Arthritis Clinical and Research Center, Peking University People's Hospital, No. 11 Xizhimen South Street, \\ Beijing 100044, China; linjianjing@bjmu.edu.cn (J.L.); linjianhao@pkuph.edu.cn (J.L.) \\ 2 Arthritis Institute, Peking University, Beijing 100044, China \\ 3 Department of Biomedical Engineering, College of Engineering, Peking University, Beijing 100871, China; \\ wanglious@pku.edu.cn \\ * Correspondence: liuqiang_pku@126.com
}

Citation: Lin, J.; Wang, L.; Lin, J.; Liu, Q. The Role of Extracellular Vesicles in the Pathogenesis, Diagnosis, and Treatment of Osteoarthritis. Molecules 2021, 26, 4987. https://doi.org/10.3390/ molecules26164987

Academic Editors: Weifeng Lin and Linyi Zhu

Received: 21 July 2021

Accepted: 14 August 2021

Published: 17 August 2021

Publisher's Note: MDPI stays neutral with regard to jurisdictional claims in published maps and institutional affiliations.

Copyright: (C) 2021 by the authors. Licensee MDPI, Basel, Switzerland. This article is an open access article distributed under the terms and conditions of the Creative Commons Attribution (CC BY) license (https:/ / creativecommons.org/licenses/by/ $4.0 /)$.

\begin{abstract}
Osteoarthritis (OA) is a degenerative joint disease that affects the entire joint and has been a tremendous burden on the health care system worldwide. Although cell therapy has made significant progress in the treatment of OA and cartilage regeneration, there are still a series of problems. Recently, more and more evidence shows that extracellular vesicles (EVs) play an important role in the progression and treatment of OA. Here, we discuss that EVs from different cell sources not only participate in OA progression, but can also be used as effective tools for the diagnosis and treatment of OA. In addition, cell pretreatment strategies and EV tissue engineering play an increasingly prominent role in the field of OA treatment. This article will systematically review the latest developments in these areas. As stated above, it may provide new insights for improving OA and cartilage regeneration.
\end{abstract}

Keywords: extracellular vesicles; osteoarthritis

\section{Introduction}

Osteoarthritis (OA) is a disease of the entire joint including structural changes in articular cartilage, subchondral bone, ligaments, joint capsule, synovium, and muscles around the joint $[1,2]$. OA affects $7 \%$ of the global population and more than 500 million people. From 1990 to 2019, the number of people globally affected increased by $48 \%$. In 2019, osteoarthritis was the world's 15th leading cause of disability, accounting for $2 \%$ of global causes of disability [3], which has been a tremendous burden on the health care system worldwide. Currently, efficient therapeutic strategies for OA treatment are still limited.

Cell therapy is considered to be a promising method for the treatment of OA and cartilage regeneration in which stem cells from different sources are widely used. However, there are still certain clinical impacts of the direct transplantation of stem cells into target tissues such as tumorigenicity, immune incompatibility, and chromosomal aberrations $[4,5]$. Because the regeneration, anti-inflammatory, immune regulation, and other functions of stem cells are mainly through their paracrine function [6], extracellular vesicles (EVs) have been widely studied. As intercellular communication carriers, EVs transfer biologically active lipids, proteins, and nucleic acids including mRNA, microRNA, and long-chain non-coding RNA (lncRNA) between cells, thereby triggering biological responses in recipient cells.

EVs cover various subtypes of membrane structures released by cells including exosomes, microvesicles, microparticles, tumor bodies, apoptotic bodies, and so on [7], which have different size and biogenesis. Although most of the current studies are conducted on exosomes, the physical characteristics of EVs overlap and are difficult to distinguish. Therefore, this review uses the collective term "EVs" to describe all of these vesicle populations. 
In this review, we first introduce the role of EVs in the pathogenesis and diagnosis of OA. Then, we review the application of EVs from different cells and stem cell pretreatment strategies of EVs in the treatment of OA. Finally, we summarize the research progress of tissue engineering in EVs research related to OA.

\section{The Role and Diagnostic Potential of EV in the Progression of OA}

Chondrocytes, synovial cells, macrophages, subchondral bone, subpatellar fat pad, tendons, and ligaments can all secrete EVs in synovial joints [8]. Pathogenic signals are transmitted between different types of cells in the joints affected by OA through EVs, breaking the balance of the joint microenvironment and aggravating the development of OA. Samavedi et al. encapsulated normal/OA chondrocytes and activated macrophages in poly(ethylene glycol) diacrylate hydrogel for co-culture to simulate the natural 3D environment of the two types of cells in OA joints. The results indicated that chondrocytes expressed significantly higher levels of pro-inflammatory factors and matrix metalloproteinases (MMPs), indicating that activated macrophages may aggravate the abnormal matrix degradation and cytokine secretion associated with chondrocytes. Similarly, macrophages co-cultured with inflammatory chondrocytes express significantly more pro-inflammatory factors interleukin-1 $\beta$ (IL-1 $\beta$ ) and vascular endothelial growth factor (VEGF), indicating that inflammatory chondrocytes may exacerbate abnormal macrophage activation [9]. Peng et al. found that THP-1 cell-derived M1 macrophages-EVs can induce the inflammatory response of temporomandibular joint (TMJ) chondrocytes by promoting the expression of inflammatory cytokines IL-8, IL6, and MMPs, and miR-1246-rich M1-EVs achieved this by inhibiting glycogen synthase kinase 3 beta (GSK3 $\beta$ ) and axis inhibition protein 2 (Axin2) and activating the Wnt/ $\beta$-catenin pathway [10]. Rossana Domenis et al. found that synovial fluid-derived exosomes from arthritis patients significantly stimulated M1 macrophages to release inflammatory cytokines IL-1 $\beta$, chemokines chemokine (C-C motif) ligand 20 (CCL20), CCL15 and C-X-C motif chemokine ligand 1 (CXCL1), and MMP12 and MMP7, which can promote the inflammatory infiltration of chondrocytes and the destruction of cartilage extracellular matrix [11]. Gao et al. found that EVs from patients with end-stage knee OA had higher levels of cytokines, especially chemokines. Synovial fluidderived EVs recruited inflammatory cells and inhibited cartilage proliferation, promoting joint degeneration [12]. EVs derived from vascular endothelial cells reduced the ability of chondrocytes to resist oxidative stress by inhibiting autophagy and p21 expression, thereby increasing cell ROS content and inducing cell apoptosis [13]. Wu et al. found that EVs derived from sclerotic osteoblasts inhibited the synthesis of the extracellular matrix (ECM) of chondrocytes and reduced the expression of chondrocyte-specific markers, and it is proved that miR-210-5p in EVs inhibited the oxygen consumption rate of chondrocytes and changed their bio-energy state, as often observed under OA conditions [14]. Ok Hee Jeon et al. found that senescent chondrocytes ( $\mathrm{SnCs}$ ) isolated from OA patients secreted more EVs than non-senescent chondrocytes, which inhibited the ECM deposition of healthy cartilage cells and can induce the senescence state of nearby cells. After removing SnCs, the composition of EV-related miRNA and proteins has changed significantly, reducing the development of $\mathrm{OA}$ and enhancing cartilage formation. This can be attributed to the differential expression of several specific miRNA (miR-30c, miR-92a, miR-34a, miR-24, miR-125a, miR-150, miR-186, and miR-223) and proteins (snake protein and polyprotein). Changes in the miRs and protein levels of synovial EVs are a potential mechanism for senescent cells to induce senescence of surrounding cells, inhibit tissue formation, and promote the development of OA [15]. Ni et al. found that OA chondrocyte-derived EVs can partially increase the production of mature IL- $1 \beta$ through miR-449a-5p/ATG4B-mediated autophagy inhibition, which may further aggravate synovitis and cartilage erosion in OA [16]. These data provide a new perspective for understanding the changes in the internal environment of OA.

The prevalence of OA in women is higher than that in men, and postmenopausal women have an increased risk of OA. Ravindra Kolhe et al. found that the female OA group 
had more miRNAs in knee synovial fluid than the male. Besides, miRNAs (miR-328-5p, miR-26a, hsa-miR-4654, miR-4707-5p, miR-4487, miR-24-3p, miR-6824-5p, miR-4740-5p, miR-8074, and miR-146a-5p) targeting toll-like receptor (TLR) and immune signaling pathways are downregulated in women with OA, while upregulated in men. It is speculated that it is precisely because of the increased expression of these miRNAs that the incidence and severity of OA in men are significantly lower than in women [17]. They also found that haptoglobin, oral mucin, and ceruloplasmin were significantly upregulated, while apolipoprotein was downregulated in female OA synovial fluid-derived EVs. Among them, haptoglobin and oral mucin will increase during inflammation and have been identified as an acute-phase glycoprotein [18]. Ceruloplasmin, as an antioxidant enzyme, is increased in the plasma of OA patients [19]. Apolipoprotein can effectively inhibit joint inflammation in rat OA model [20]. In conclusion, the changes in miRNA and protein content in synovial EVs of OA patients are gender-specific, which explains the increase in the prevalence and severity of OA in women.

OA is diagnosed through imaging and physical examination, which are relatively poor for the early diagnosis of OA. EVs reflect the physiological and pathological condition of cells, and may have the potential as diagnostic biomarkers for OA. At present, the conventional characterization methods of EVs mainly include western blot of specific markers, transmission electron microscopy (TEM), and nanoparticle tracking analysis (NTA). The same is true for OA-specific EV characterization techniques, as shown in Table 1. Since synovial fluid has a direct and close relationship with synovium, articular cartilage, and other knee joint tissues, synovial fluid can be used to monitor the pathophysiological changes of the joint space. Anne-Mari Mustonen et al. developed an applicable method based on confocal laser scanning microscopy (CLSM) and image analysis to quantify EVs, hyaluronic acid (HA)-particles, and hyaluronic acid-coated EVs (HA-EVs) in synovial fluid of human knee joints. The fluorescence intensity of EVs and HA-particles of RA was lower than that of the control group and the OA group, which were clearly separated by discriminant analysis based on CLSM data [21]. Zhao et al. found that the expression of EVs in the synovial fluid of OA patients was much higher than that of healthy people, but there was no significant difference between early OA and late OA. However, the expression of lncRNA PCGEM1 in EVs from synovial fluid is not only different between OA patients and healthy people, but also shows significant differences at different stages of OA. In addition, since the WOMAC index is highly correlated with the expression of lncRNA PCGEM1 in EVs, it is speculated that the severity of OA may be related to lncRNA PCGEM1, which may be a powerful indicator to distinguish early OA from late OA [22]. Studies have also found that compared with healthy people, LncRNA PVT1 in serum EVs of patients with osteoarthritis is significantly upregulated [23], while the level of miR-193b in plasma EVs of patients with OA is lower than that of healthy people [24].

Table 1. Characterization methods of OA-specific EVs.

\begin{tabular}{|c|c|c|c|c|c|}
\hline Source & NTA & TEM & Western Blot & Flow Cytometry & Reference \\
\hline Synovial fluid & $\begin{array}{l}\text { The majority of the } \\
\text { particles were } \\
\text { within the range } \\
\text { size of } 100 \mathrm{~nm} \text {. }\end{array}$ & & $\begin{array}{l}\text { CD9, CD63, CD81, } \\
\text { and TSG101 }\end{array}$ & $\begin{array}{l}\text { CD9, CD81, and } \\
\text { CD63 }\end{array}$ & $\begin{array}{l}\text { Domenis et al., } \\
2017 \text { [11] }\end{array}$ \\
\hline Synovial fluid & $\begin{array}{l}\text { The particles were } \\
\text { with the range size } \\
\text { of } 100-125 \mathrm{~nm} \text {. } \\
\text { KL } 3-4 \text { SF } \\
\text { contained more } \\
\text { exosome particles } \\
\text { than that of } \\
\text { KL } 1-2 \text {. }\end{array}$ & $\begin{array}{l}\text { Round vesicles } \\
\text { with an } \\
\text { approximate } \\
\text { diameter of } \\
50-200 \mathrm{~nm}\end{array}$ & $\begin{array}{l}\text { CD9, CD63, and } \\
\text { CD81 }\end{array}$ & & Gao et al., 2020 [12] \\
\hline
\end{tabular}


Table 1. Cont.

\begin{tabular}{|c|c|c|c|c|c|}
\hline Source & NTA & TEM & Western Blot & Flow Cytometry & Reference \\
\hline Synovial fluid & $\begin{array}{l}\text { EV size and } \\
\text { concentration in } \\
\text { synovial fluid from } \\
\text { both OA and } \\
\text { normal donors } \\
\text { were similar }\end{array}$ & & & & $\begin{array}{c}\text { Jeon et al., } 2019 \\
{[15]}\end{array}$ \\
\hline Synovial fluid & $\begin{array}{l}\text { The size and } \\
\text { concentration of } \\
\text { EVs are almost } \\
\text { similar between } \\
\text { OA and NON-OA } \\
\text { patient's } \\
\text { synovial fluid. }\end{array}$ & $\begin{array}{l}\sim 100( \pm 10) \mathrm{nm} \\
\text { diameter } \\
\text { size ranges. }\end{array}$ & $\begin{array}{l}\text { Tsg101, CD63, and } \\
\text { CD81 }\end{array}$ & & $\begin{array}{c}\text { Kolhe et al., } 2021 \\
\text { [17] }\end{array}$ \\
\hline $\begin{array}{l}\text { Synovial fluid } \\
\text { and plasma }\end{array}$ & $\begin{array}{l}\text { EVs isolated from } \\
\text { plasma and } \\
\text { synovial sample } \\
\text { were in size with } \\
100 \mathrm{~nm}\end{array}$ & $\begin{array}{l}\text { Round-shaped or } \\
\text { oval-shaped in } \\
\text { morphology. }\end{array}$ & $\begin{array}{l}\text { CD9, CD63, and } \\
\text { TSG101 }\end{array}$ & $\begin{array}{l}\text { The expression of } \\
\text { exosomal lncRNA } \\
\text { PCGEM1 from } \\
\text { synovial fluid in } \\
\text { early OA and } \\
\text { late-stage OA was } \\
\text { markedly higher } \\
\text { than that } \\
\text { in controls. }\end{array}$ & $\begin{array}{c}\text { Zhao et al., } 2018 \\
\text { [22] }\end{array}$ \\
\hline Serum & $\begin{array}{l}\text { The exosomes } \\
\text { were circular in } \\
\text { shape and } 40-100 \\
\mathrm{~nm} \text { in the C28/I2 } \\
\text { cells and the serum } \\
\text { of OA patients and } \\
\text { healthy volunteers }\end{array}$ & & CD9 and CD63 & & $\begin{array}{c}\text { Meng et al., } 2020 \\
\text { [23] }\end{array}$ \\
\hline Plasma & $\begin{array}{l}\text { Most of these } \\
\text { vesicles ranged } \\
\text { from } 50 \text { to } 200 \mathrm{~nm} \\
\text { in size }\end{array}$ & $\begin{array}{l}\text { Hollow spherical } \\
\text { microvesicles. }\end{array}$ & CD63 and CD9 & & $\begin{array}{c}\text { Meng et al., } 2018 \\
{[24]}\end{array}$ \\
\hline
\end{tabular}

\section{Therapeutic Applications of EVs in OA}

In recent years, more and more studies have shown that EVs from different types of cells have a definite therapeutic effect on OA and cartilage damage, as shown in Table 2.

\subsection{Stem Cells}

\subsubsection{Bone Marrow Mesenchymal Stem Cells (BMMSC)}

A large number of studies have shown that BMMSC-EVs can inhibit the adverse effects of inflammatory mediators on cartilage homeostasis $[25,26]$, which may be achieved by downregulating the pro-inflammatory Erk1/2, PI3K/Akt, p38, TAK1, and NF- $\mathrm{kB}$ signaling pathways $[27,28]$. Chen et al. found that the expression of E74-like factor 3 (ELF3) increased and miR-136-5p decreased in clinical samples of traumatic OA cartilage tissue. The BMMSC-EVs showed rich levels of miR-136-5p, and the expression of ELF3 in chondrocytes decreased after EV internalization. In a mouse model of post-traumatic OA, EV miR-136-5p was found to reduce the degradation of cartilage extracellular matrix. These data provided evidence that BMMSC-EVs miR-136-5p can promote chondrocyte migration in vitro and inhibit cartilage degeneration in vivo, thereby inhibiting OA [29]. Zhang et al. proved that BMMSC-EVs can promote the phenotypic transformation of synovial macrophages from M1 to M2, reduce synovial hyperplasia, and inflammatory cell infiltration, significantly reducing the levels of pro-inflammatory cytokines IL-1 $\beta$ and TNF- $\alpha$ [30]. Li et al. found that 
EVs derived from BMMSC can relieve pain by eliminating abnormal CGRP-positive nerves and abnormal H-type blood vessel formation in the subchondral bone of lumbar facet joint osteoarthritis in mice. Moreover, BMMSC-EVs alleviated cartilage degeneration and inhibited the expression of tartrate-resistant acid phosphatase and RANKL-RANK-TRAF6 signal activation to promote subchondral bone remodeling [31]. Zhou et al. obtained a special type of MSC from the bone marrow of the tissues removed from the hands of patients with polydactyly, and found that PBMSC-EVs stimulated the migration and proliferation of chondrocytes. Injection of pBMSC-EVs and BMSC-EVs reduced OA in the OA mouse model, but compared with BMSC-EVs, pBMSC-EVs had a better therapeutic effect. Therefore, pBMSC-EVs may represent a new OA treatment method [32].

\subsubsection{Adipose-Derived Mesenchymal Stem Cells (ADSC)}

Since it is relatively feasible to obtain fat from patients through liposuction or arthroscopic surgery in clinic, EVs derived from adipose-derived mesenchymal stem cells may be a potential treatment for OA in the future. Wu et al. studied EVs derived from infrapatellar fat pad (IPFP) MSCs that improved the severity of OA, inhibited chondrocyte apoptosis, enhanced matrix synthesis, and reduced the expression of catabolic factors MMP13 and a disintegrin and metalloproteinase with thrombospondin motifs 5 (ADAMTS5). The mechanism may be related to the inhibition of the mTOR-autophagy pathway regulated by miR100-5p [33]. Carola Cavallo et al. emphasized the potential of ADSC-EVs to counteract IL-1 $\beta$-induced inflammatory gene expression and protein release in chondrocytes and synovial cells [34]. Studies have found that intra-articular injection of ADSC-EVs significantly slowed down the progression of OA of mouse models and protects cartilage from degeneration. Besides, injection of hADSC-EVs inhibited the infiltration of M1 macrophages into the synovium [35]. Studies have also shown that EVs from ADSC downregulated the senescence-related $\beta$-galactosidase activity of OA osteoblasts and the accumulation of $\gamma$ $\mathrm{H} 2 \mathrm{AX}$ lesions. In addition, they reduced the production of inflammatory mediators IL-6 and prostaglandin E2 [36]. Zhao et al. found that co-culture of ADSC-EVs and activated synovial fibroblasts can downregulate the expression of pro-inflammatory markers IL-6, NF- $\mathrm{kB}$, and tumor necrosis factor- $\alpha$, and protect articular cartilage cells from apoptosis. EV treatment promoted the cartilage formation of periosteal cells and increased cartilage formation markers including type II collagen and $\beta$-catenin [37].

\subsubsection{Embryonic Mesenchymal Stem Cells (ESC)}

Zhang et al. demonstrated that human ESC-EVs can promote the repair of criticalsize osteochondral defects in an adult immunocompetent rat model for the first time [38]. Wang et al. found that intra-articular injection of ESC reduced cartilage destruction and matrix degradation in the destabilization of the medial meniscus (DMM) model through ESC-derived EVs [39]. Zhang et al. found that ESC-EVs enhanced the synthesis of sulfated glycosaminoglycan (s-GAG) blocked by IL-1 $\beta$, and inhibited the production of nitric oxide and MMP13 induced by IL-1 $\beta$. These effects are partially eliminated by adenosine receptor activation and inhibition of phosphorylation of AKT, ERK, and AMPK, which promotes the repair and regeneration of TMJ in OA [40]. Studies detected 200 secreted factors and 754 miRNAs in EVs of amniotic mesenchymal stem cells (AMSC). The analysis based on miRNAs related to OA and tendinopathy showed that the most abundant EV-miRNA can induce polarization of M2 macrophages, and then protect the tendon and cartilage. Overall, the presence of key regulatory molecules and miRNAs explains the promising therapeutic results of AMSCs and their secretion group in the treatment of musculoskeletal diseases [41].

\subsubsection{Other Stem Cells}

Wang et al. found that the miR-31 packaged by synovial membrane MSCs-EV enhanced the proliferation and migration of chondrocytes, cartilage formation by targeting lysine-specific demethylase 2A (KDM2A), and improved knee OA [42]. Zhu et al. compared 
the effectiveness of EVs isolated from synovial membrane MSC (SMMSC-EVs) or induced pluripotent stem cell-derived MSCs (iMSC-EVs) for the treatment of OA, and found that iMSC-EVs had a better therapeutic effect than SMMSC-EVs in the collagenase-induced OA mouse model [43]. Luo et al. found that human deciduous tooth stem cell-EVs inhibited the expression of IL-6, IL-8, MMP1, MMP3, MMP9, and MMP13 as well as ADAMTS5 of TMJ chondrocyte through miR-100-5p/mTOR [44].

\subsection{Other Cells}

Wang et al. found that there were proteins in normal chondrocyte EVs that belonged to mitochondria and participated in immune system processes. Chondrocyte-derived EVs can restore mitochondrial dysfunction and polarize macrophages to the M2 phenotype. Intraarticular injection of EVs successfully prevented the development of OA [45]. Bai et al. cocultured M2 macrophage EVs and chondrocytes to find that M2-EVs significantly increased cartilage-specific genes and proteins by delivering lncRNA MM2P to chondrocytes to promote cartilage repair [46].

\subsection{Blood}

Many basic, preclinical, and even clinical case studies and trials have reported the ability of platelet-rich plasma (PRP) to improve musculoskeletal diseases including osteoarthritis. However, due to the lack of standardization of PRP products, many people are not convinced by this result [47]. Isolated EVs from different cell sources have been suggested as therapeutic agents in OA cartilage recovery. Autologous EVs from blood products have advantages over cell-derived EVs because they do not require cell culture, do not involve cell therapy, do not cause uncontrolled differentiation of MSCs (such as undesired ossification) that may cause related adverse effects, and do not have risk of disease transmission from the donor to the recipient. Additionally, EV treatment can be standardized in terms of EV concentration compared with whole blood products [48]. Otahal et al. found that the EVs in citrate anticoagulated platelet-rich plasma (CPRP) and hyperacute serum (hypACT) were mainly derived from platelets, and the proportion of EVs derived from red blood cells and monocytes was very low. Compared with whole blood products, EV treatment of chondrocytes enhanced the expression of anabolic markers such as type II collagen, SRY-box transcription factor 9 (SOX9), and agglomerans, while preventing the release of pro-inflammatory cytokines. This highlighted the potential of autologous blood-derived EVs as a regulator of cartilage extracellular matrix metabolism and inflammation, and as a candidate for a new cell-free treatment of OA [48]. Liu et al. found that PRP-derived EVs (PRP-EVs) can significantly promote the proliferation and migration of chondrocytes and reduce the apoptotic rate of OA chondrocytes. PRP-EVs, as a carrier containing PRP-derived growth factors, provide a new treatment method for OA by activating the Wnt/ $\beta$-catenin signaling pathway [49]. 
Table 2. Therapeutic applications of EVs in OA.

\begin{tabular}{|c|c|c|c|c|}
\hline \multicolumn{5}{|c|}{ Treated In Vitro } \\
\hline Source & Cell(s) Used & Administration and Dose & Results & Reference \\
\hline BMMSC & Human chondrocytes & EVs were applied to cells at $600 \mu \mathrm{L}$. & $\begin{array}{l}\text { BMMSC-derived EVs showed a rich level of } \\
\text { miR-136-5p, which can be internalized by } \\
\text { chondrocytes. MiR-136-5p promoted the } \\
\text { migration of chondrocytes, increased the } \\
\text { expression of collagen II, proteoglycan and } \\
\text { SOX9, and decreased the expression of } \\
\text { MMP-13. In addition, the expression of ELF3 } \\
\text { in chondrocytes decreased after the } \\
\text { internalization of EVs. }\end{array}$ & Chen et al., 2020 [29] \\
\hline BMMSC & $\begin{array}{l}\text { The murine macrophage RAW } 264.7 \\
\text { cell line treated with LPS } \\
(50 \mathrm{ng} / \mathrm{mL}) \\
\text { co-cultured macrophages with } \\
\text { chondrocytes for } 72 \mathrm{~h}\end{array}$ & Cells treated with EVs for $24 \mathrm{~h}$. & $\begin{array}{l}\text { In EVs treatment group, the M2 ratio } \\
\text { increased, and the levels of pro-inflammatory } \\
\text { cytokines IL-1 } \beta \text {, IL- } 6 \text {, and TNF- } \alpha \text { were } \\
\text { significantly reduced, while the levels of } \\
\text { anti-inflammatory cytokine IL-10 were } \\
\text { significantly increased. Besides, the } \\
\text { expression of collagen X and runx } 2 \text { decreased, } \\
\text { while the expression of collagen II and } \\
\text { sox9 increased. }\end{array}$ & Zhang et al., 2020 [30] \\
\hline pBMMSC & Human chondrocytes & $\begin{array}{l}\text { Cells treated with } 1,5, \text { or } 10 \mu \mathrm{g} / \mathrm{mL} \\
\text { EVs for } 24 \mathrm{~h} \text {. }\end{array}$ & $\begin{array}{l}\text { EVs enhanced chondrocyte migration and } \\
\text { proliferation }\end{array}$ & Zhou et al., 2020 [32] \\
\hline ADSC & Human chondrocytes & $\begin{array}{l}\text { Cells treated with } 1,5 \text { and } 10 \times 10^{8} \\
\text { particles } / \mathrm{mL} \text { EVs for } \\
24 \mathrm{~h} \text {. }\end{array}$ & $\begin{array}{l}\text { EVs enhanced the expression of anabolic } \\
\text { marker collagen II and decreased the } \\
\text { expression of catabolic marker MMP13 and } \\
\text { ADAMTS5. } \\
\text { EVs can significantly increase the autophagy } \\
\text { level of chondrocytes partially through } \\
\text { mTOR inhibition. }\end{array}$ & Wu et al., 2020 [33] \\
\hline ADSC & $\begin{array}{l}\text { Human chondrocytes treated with } \\
\text { IL-1 } \beta(10 \mathrm{ng} / \mathrm{mL}) \text { for } 18 \mathrm{~h}\end{array}$ & $\begin{array}{l}\text { Cells treated with } 10 \mu \mathrm{g} / \mathrm{mL} \text { EVs for } \\
4 \mathrm{~h} \text { and } 15 \mathrm{~h} .\end{array}$ & $\begin{array}{l}\text { EVs significantly increased the expression of } \\
\text { some cytokine/chemokine genes (IL-1 } \beta \text {, } \\
\text { MCP-1) and angiogenic factors (VEGF) in 4-h } \\
\text { treatment group, but decreased the levels of } \\
\text { IL-6, IL-8, MCP-1, MMP-1 in 15-h } \\
\text { treatment group. }\end{array}$ & Cavallo et al., 2021 [34] \\
\hline
\end{tabular}


Table 2. Cont.

\begin{tabular}{|c|c|c|c|c|}
\hline \multicolumn{5}{|c|}{ Treated In Vitro } \\
\hline Source & Cell(s) Used & Administration and Dose & Results & Reference \\
\hline ADSC & $\begin{array}{l}\text { Human chondrocytes treated with } \\
\text { IL-1ß }(5 \mathrm{ng} / \mathrm{mL}) \text { for } 72 \mathrm{~h}\end{array}$ & $\begin{array}{l}\text { Cells treated with } 1 \times 10^{8} \text { and } \\
2 \times 10^{8} \text { particles } / \mathrm{mL} \text { EVs for } 72 \mathrm{~h}\end{array}$ & $\begin{array}{l}\text { EVs inhibited IL- } 1 \beta \text {-induced MMP } \\
\text { production and significantly increased the } \\
\text { mRNA expression of type II collagen } \\
\text { inhibited by IL- } 1 \beta \text { in human } \\
\text { OA chondrocytes. }\end{array}$ & Chang et al., 2020 [35] \\
\hline ADSC & $\begin{array}{l}\text { Human osteoblasts treated with } \\
\text { IL-1 } \beta(10 \mathrm{ng} / \mathrm{mL}) \text { for } 24 \mathrm{~h}\end{array}$ & $\begin{array}{l}\text { Cells treated with } 7.2 \times 10^{7} \\
\text { particles } / \mathrm{mL} \text { EVs for } 7 \text { days. }\end{array}$ & $\begin{array}{l}\text { EVs downregulated the senescence-related } \\
\beta \text {-galactosidase activity of OA osteoblasts } \\
\text { and the accumulation of } \gamma \text { H2AX lesions that } \\
\text { represent DNA damage. In addition, EVs } \\
\text { reduced the production of inflammatory } \\
\text { mediators IL- } 6 \text { and prostaglandin E2. }\end{array}$ & Vian et al., 2017 [36] \\
\hline ADSC & $\begin{array}{l}\text { human chondrocytes treated with } \\
\mathrm{H}_{2} \mathrm{O}_{2}(100 \mu \mathrm{M}) \text { for } 1 \mathrm{~h}\end{array}$ & $\begin{array}{l}\text { Cells treated with } 1,5 \text { and } 10 \times 10^{10} \\
\text { particles } / \mathrm{mL} \text { EVs for } 7 \text { days. }\end{array}$ & ADSC-derived EVs inhibited apoptosis. & Zhao et al., 2017 [37] \\
\hline ESC & $\begin{array}{l}\text { Human chondrocytes treated with } \\
\text { IL-1ß }(2 \mathrm{ng} / \mathrm{mL}) \text { for } 48 \mathrm{~h}\end{array}$ & $\begin{array}{l}\text { Cells treated with } 1,5 \text { and } 10 \times 10^{8} \\
\text { particles } / \mathrm{mL} \text { EVs for } 24 \mathrm{~h} \text {. }\end{array}$ & $\begin{array}{l}\text { As the dose of EVs increased, Col II secreted } \\
\text { by chondrocytes gradually increased, and } \\
\text { ADAMTS5 decreased gradually. }\end{array}$ & Wang et al., 2017 [39] \\
\hline ESC & $\begin{array}{l}\text { Rat TMJ condylar chondrocytes } \\
\text { treated with IL-1 } \beta(1 \mathrm{ng} / \mathrm{mL}) \text { for } \\
24 \mathrm{~h} .\end{array}$ & $\begin{array}{l}\text { Cells treated with } 5 \mu \mathrm{g} / \mathrm{mL} \text { EVs for } \\
48 \mathrm{~h} \text {. }\end{array}$ & $\begin{array}{l}\text { EVs enhanced the synthesis of s-GAG } \\
\text { blocked by IL-1 } \beta \text {, and inhibited the } \\
\text { production of NO and MMP13 induced } \\
\text { by IL- } 1 \beta \text {. }\end{array}$ & Zhang et al., 2019 [40] \\
\hline SMSC & Human chondrocytes & $\begin{array}{l}\text { Cells treated with chondrocyte } \\
\text { culture medium containing } 600 \mu \mathrm{L} \\
\text { EV for } 12 \mathrm{~h} \text {. }\end{array}$ & $\begin{array}{l}\text { EVs can effectively promote the proliferation } \\
\text { of chondrocytes. EVs loaded with miR-31 } \\
\text { directly targeted KDM2A in chondrocytes to } \\
\text { promote cartilage production. }\end{array}$ & Wang et al., 2020 [42] \\
\hline iMSC & Human chondrocytes & $\begin{array}{l}\text { Cells treated with } 1 \times 10^{7} \text { and } 1 \times \\
10^{8} \text { particles } / \mathrm{mL} \mathrm{EVs} \mathrm{for} 24 \mathrm{~h} \text { and } \\
48 \mathrm{~h} .\end{array}$ & $\begin{array}{l}\text { Both iMSC-EVs and SMMSC-EVs } \\
\text { significantly enhanced the motility of } \\
\text { chondrocytes, and iMSC-EVs was more } \\
\text { effective than SMMSC-EVs in increasing } \\
\text { motility for } 24 \text { and } 48 \mathrm{~h} \text {. }\end{array}$ & Zhu et al., 2017 [43] \\
\hline
\end{tabular}


Table 2. Cont.

\begin{tabular}{|c|c|c|c|c|}
\hline \multicolumn{5}{|c|}{ Treated In Vitro } \\
\hline Source & Cell(s) Used & Administration and Dose & Results & Reference \\
\hline $\begin{array}{l}\text { Stem cells from human } \\
\text { exfoliated deciduous teeth }\end{array}$ & $\begin{array}{l}\text { human mandibular condyles } \\
\text { chondrocytes treated with IL-1 } \beta \\
(10 \mathrm{ng} / \mathrm{mL}) \text { for } 24 \mathrm{~h}\end{array}$ & $\begin{array}{l}\text { Cells pretreated with } 150 \mu \mathrm{L} \\
\left(1.5 \times 10^{7} \text { particles }\right) \text { EVs for } 2 \mathrm{~h} \text {. }\end{array}$ & $\begin{array}{l}\text { EVs inhibited the expression levels of } \\
\text { pro-inflammatory cytokines IL-6 and IL-8 } \\
\text { and proteases MMP1, MMP3, MMP9, } \\
\text { MMP13, and ADAMTS5. }\end{array}$ & Luo et al., 2019 [44] \\
\hline Chondrocyte & $\begin{array}{l}\text { Mouse chondrocytes treated with } \\
\text { IL-1 } \beta(10 \mathrm{ng} / \mathrm{mL}) \text { for } 72 \mathrm{~h}\end{array}$ & $\begin{array}{l}\text { Cells treated with EVs }(200 \mu \mathrm{g} / \mathrm{mL}) \\
\text { for } 48 \mathrm{~h} .\end{array}$ & $\begin{array}{l}\text { EVs reduced the protein levels of MMP13 and } \\
\text { Adamts 5, and increased the expression levels } \\
\text { of collagen II and proteoglycans, and } \\
\text { eliminated mitochondrial dysfunction. }\end{array}$ & Zheng et al., 2019 [45] \\
\hline $\begin{array}{l}\text { Plasma- and serum-based } \\
\text { autologous blood-derived } \\
\text { products }\end{array}$ & $\begin{array}{l}\text { Human chondrocytes treated with } \\
\text { IL-1 } \beta(10 \mathrm{ng} / \mathrm{mL})\end{array}$ & $\begin{array}{l}\text { Cells treated with medium } \\
\text { supplemented with } 1.42 \times 10^{9} \text { EVs. }\end{array}$ & $\begin{array}{l}\text { EVs treatment of chondrocytes enhanced the } \\
\text { expression of anabolic markers, such as type } \\
\text { II collagen, SOX9 and aggregates, and } \\
\text { prevented the release of pro-inflammatory } \\
\text { cytokines NF-kB and COX2. }\end{array}$ & Otahal et al., 2020 [48] \\
\hline Platelet-rich plasma (PRP) & $\begin{array}{l}\text { Rabbit chondrocytes treated with } \\
\text { IL-1 } \beta(10 \mathrm{ng} / \mathrm{mL})\end{array}$ & $\begin{array}{l}\text { Cells treated with PRP-EVs } \\
(5 \mu \mathrm{g} / \mathrm{mL} \text { or } 50 \mu \mathrm{g} / \mathrm{mL}) \text { for } 24 \mathrm{~h} \text {. }\end{array}$ & $\begin{array}{l}\text { PRP-EVs promoted the proliferation and } \\
\text { migration of chondrocytes through the } \\
\text { Wnt/ } \beta \text {-catenin signaling pathway, inhibited } \\
\text { the release of TNF- } \alpha \text {, and inhibited } \\
\text { chondrocyte apoptosis. }\end{array}$ & Liu et al., 2019 [49] \\
\hline \multicolumn{5}{|c|}{ Treated In Vivo } \\
\hline Source & Model(s) Used & Administration and Dose & Results & Reference \\
\hline BMMSC & $\begin{array}{l}\text { A single mechanical load was } \\
\text { applied to the mouse joint }(1 \mathrm{mM} / \mathrm{s} \\
\text { to } 12 \mathrm{~N}) \text {, causing the tibia to move } \\
\text { forward relative to the femur and } \\
\text { extended the anterior cruciate } \\
\text { ligament beyond the point of failure. }\end{array}$ & $\begin{array}{l}\text { Intra-articular injection of with } \\
100 \mu \mathrm{L} \text { of } 10^{11} \text { particles } / \mathrm{mL} \text { EVs } \\
\text { immediately after the injury. }\end{array}$ & $\begin{array}{l}\text { EVs miR-136-5p can reduce the degradation } \\
\text { of cartilage extracellular matrix. }\end{array}$ & Chen et al., 2020 [29] \\
\hline
\end{tabular}


Table 2. Cont.

\section{Treated In Vitro}

Source Cell(s) Used Administration and Dose

Rat model of OA: Modified Hulth technique: the anterior cruciate ligament was cut, and the medial meniscus was removed.
At 4 weeks post-operation, rats were injected intra-articularly with $10 \mathrm{ul}$ of PBS or BMSC-derived EVs $\left(10^{10}\right.$ particles $/ \mathrm{mL}$ ) for 3 days for

4 weeks.
Mice were operated by resection of the lumbar 3rd-lumbar 5th (L3-L5) spinous processes along with the supraspinous and interspinous

ligaments to induce instability in the lumbar spine.

pBMMSC

Collagenase-induced mouse model of OA.

ADSC

\section{Surgical destabilization of the} medial meniscus (DMM)
The mice were injected weekly till four weeks right after surgery with EVs $(200 \mu \mathrm{g}$ of EVs in $200 \mu \mathrm{L}$ PBS

via the tail vein.

The mice were injected with

pBMSC-EVs on days 7, 14 and 21 respectively.

The mice were given multiple intra-articular injections of $10 \mu \mathrm{L}$

EVs $\left(10^{10}\right.$ particles $\left./ \mathrm{mL}\right)$ for 4 weeks (twice a week).

\section{Results}

Reference

The cartilage degradation in the EVs group

was less, the chondrocytes maintained close

to normal morphology and distribution, and

the number and surface area of osteophytes

around the joints were smaller than those in

the PBS group. The expression of

hypertrophic genes, collagen $\mathrm{X}$ and runx2

was reduced. The expression of the cartilage

Zhang et al., 2020 [30]

forming genes type II collagen and sox 9

increased.

EVs inhibit cartilage degradation and

osteophyte formation during the progression of rat OA.

EVs treatment significantly increased the

expression of ACAN and decreased the

expression of MMP13. BMSCs-EVs can

attenuate abnormal nerve invasion and

angiogenesis of subchondral bone, inhibit

osteoclastogenesis by inhibiting the

Li et al., 2020 [31]

RANKL-RANK-TRAF6 signaling pathway in

subchondral bone and promote cartilage and subchondral bone remodeling.

pBMSC-EVs can reduce cartilage damage caused by OA

Zhou et al., 2020 [32]

EVs could enter the damaged area of articular cartilage, promote chondrocyte catabolism and inhibit its anabolism, and significantly

prevented the cartilage destruction and

Wu et al., 2020 [33] partially improved the gait abnormality. 
Table 2. Cont.

\begin{tabular}{|c|c|c|c|c|}
\hline \multicolumn{5}{|c|}{ Treated In Vitro } \\
\hline Source & Cell(s) Used & Administration and Dose & Results & Reference \\
\hline ADSC & $\begin{array}{l}\text { Monosodium iodoacetate } \\
\text { (MIA)-induced OA. }\end{array}$ & $\begin{array}{l}\text { Starting from } 5 \text { weeks after DMM } \\
\text { surgery, hASC-EVs }\left(10^{8} \text { particles in }\right. \\
\text { a volume of } 6 \mu \mathrm{L}) \text { were injected once } \\
\text { a week for } 6 \text { weeks }\end{array}$ & $\begin{array}{l}\text { EVs treatment effectively prevented } \\
\text { proteoglycan degradation and prevented the } \\
\text { progression of cartilage destruction after } \\
\text { MIA injection. }\end{array}$ & Chang et al., 2020 [35] \\
\hline ESC & $\begin{array}{l}\text { Osteochondral defects were created } \\
\text { on the trochlear grooves of both } \\
\text { distal femurs in adult rats. }\end{array}$ & $\begin{array}{l}\text { Intra-articular injection of exosomes } \\
(100 \mu \mathrm{g} \text { EVs per } 100 \mu \mathrm{L} \text { injection) } \\
\text { was performed after surgery, and } \\
\text { subsequently on a weekly basis for } 6 \\
\text { and } 12 \text { weeks. }\end{array}$ & $\begin{array}{l}\text { Defects after EVs treatment showed complete } \\
\text { recovery of cartilage and subchondral bone, } \\
\text { with the characteristics including hyaline } \\
\text { cartilage with good surface regularity, } \\
\text { complete integration with adjacent cartilage, } \\
\text { and extracellular matrix deposition that was } \\
\text { very similar to the unoperated control. }\end{array}$ & Zhang et al., 2016 [38] \\
\hline ESC & $\begin{array}{l}\text { Surgical destabilization of the } \\
\text { medial meniscus (DMM). }\end{array}$ & $\begin{array}{l}\text { Inject } 5 \mu \mathrm{L} \text { ESC-EVs }\left(1 \times 10^{6} / \text { joint }\right) \\
\text { per joint, once every } 3 \text { days for } 4 \\
\text { weeks. }\end{array}$ & $\begin{array}{l}\text { Cartilage in the EVs group showed stronger } \\
\text { Col II specific staining, much weaker } \\
\text { ADAMTS5 specific staining, and } \\
\text { proteoglycan specific staining than the PBS } \\
\text { group. }\end{array}$ & Wang et al., 2017 [39] \\
\hline SMSC & $\begin{array}{l}\text { OA model was established by } \\
\text { completely transecting the medial } \\
\text { collateral ligament and medial } \\
\text { meniscus, cutting the meniscus at } \\
\text { the narrowest point without } \\
\text { damaging the tibial surface, and } \\
\text { transecting the anterior cruciate } \\
\text { ligament. }\end{array}$ & $\begin{array}{l}5 \mu \mathrm{L} \text { SMSC-EV particles per } \mathrm{mL} \\
\text { were injected into the articular } \\
\text { cavity on the first day of each week } \\
\text { from the } 5 \text { th to the } 8 \text { th week after } \\
\text { surgery. }\end{array}$ & $\begin{array}{l}\text { EVs encapsulated miR-31 inhibited knee joint } \\
\text { OA through the KDM2A/E2F1/PTTG1 axis. }\end{array}$ & Wang et al., 2020 [42] \\
\hline iMSC & $\begin{array}{l}\text { Collagenase-induced mouse model } \\
\text { of OA. }\end{array}$ & $\begin{array}{l}\text { The mice were injected } \\
\text { intra-articularly with } 8 \mu \mathrm{L} \\
\text { iMSC-EVs }\left(10^{10} / \mathrm{mL}\right) \text { on days } 7,14 \\
\text { and } 21 .\end{array}$ & $\begin{array}{l}\text { EVs group had stronger type II collagen } \\
\text { expression and safranine staining than } \\
\text { SMMSC-EVs group. }\end{array}$ & Zhu et al., 2017 [43] \\
\hline
\end{tabular}


Table 2. Cont.

\begin{tabular}{|c|c|c|c|c|}
\hline \multicolumn{5}{|c|}{ Treated In Vitro } \\
\hline Source & Cell(s) Used & Administration and Dose & Results & Reference \\
\hline Chondrocyte & $\begin{array}{l}\text { Anterior cruciate ligament } \\
\text { transection (ACLT). }\end{array}$ & $\begin{array}{l}10 \text { days after surgery, mice received } \\
\text { intra-articular injections of } 200 \mu \mathrm{g} \\
\text { exosomes every week }\end{array}$ & $\begin{array}{l}\text { Almost complete preservation of both } \\
\text { femoral and tibial cartilage and effective } \\
\text { prevention of the development of OA were } \\
\text { showed in EVs group. EVs can increase the } \\
\text { infiltration of M2 macrophages in the } \\
\text { synovium, while the M1 } \\
\text { macrophages decrease. }\end{array}$ & Zheng et al., 2019 [45] \\
\hline M2 macrophage & $\begin{array}{l}\text { Surgical destabilization of the } \\
\text { medial meniscus (DMM). }\end{array}$ & $\begin{array}{l}\text { One week after DMM surgery, mice } \\
\text { were treated by tail vein injection. }\end{array}$ & $\begin{array}{l}\text { EVs injection reversed abnormal subchondral } \\
\text { bone formation and sclerosis. }\end{array}$ & Bai et al., 2020 [46] \\
\hline Platelet-rich plasma (PRP) & $\begin{array}{l}\text { Resection of the medial collateral } \\
\text { ligament, anterior cruciate ligament } \\
\text { (ACL) and medial meniscus of the } \\
\text { left knee. }\end{array}$ & $\begin{array}{l}\text { Inject } 100 \mu \mathrm{g} / \mathrm{mL} \text { PRP-EVs into the } \\
\text { joint cavity once a week for } 6 \text { weeks. }\end{array}$ & $\begin{array}{l}\text { PRP-EVs reversed the decrease in collagen II } \\
\text { and RUNX2 protein expression caused by } \\
\text { OA, promoted cartilage repair, and inhibits } \\
\text { osteoarthritis }\end{array}$ & Liu et al., 2019 [49] \\
\hline
\end{tabular}




\section{Cell Pretreatment Strategy}

Studies have shown that pretreatment is an effective way to improve the ability of cells to resist adverse microenvironments. Stem cell pretreatment can improve cell survival and differentiation potential, regulate immune response, inhibit fibrosis, and enhance cell secretion of anti-inflammatory factors [50]. Therefore, a stem cell pretreatment strategy has also received a lot of attention in the field of releasing EVs to treat OA.

\subsection{Physical Factors}

The strategy of using physical factors to stimulate cells to produce EVs has been tried in the OA and cartilage fields. Research has shown that LIPUS can promote BMSC cartilage formation [51,52]. Liao et al. studied the effect of LIPUS combined with BMSC-EVs on OA cartilage and concluded that LIPUS promoted BMSC-EVs to inhibit OA inflammation, and further promoted its increase in cartilage extracellular matrix synthesis and chondrocyte proliferation, promoting the regeneration of articular cartilage [53]. Although physical stimulation of cells to produce EVs is rarely used in the treatment of OA/cartilage injury, we still believe that this strategy is of great value.

\subsection{Pharmacological Agents}

Due to the low solubility, instability, and rapid systemic elimination, the bioavailability of a large number of drugs is low. Therefore, the use of drugs to pretreat stem cells and improve the therapeutic effect of EVs on OA is another pretreatment strategy. Research by Li et al. showed that compared with the control BMSC and free curcumin, EVs derived from curcumin treated BMSC (Cur-EVs) can significantly reduce the catabolic genes in OA chondrocytes induced by IL- $1 \beta$, and increase the expression of anabolic genes. These effects may be partly attributed to the upregulated expression of hsa-miR-126-3p in target cells induced by Cur-EVs, which results in reduced phosphorylation of pro-inflammatory signaling pathway components [54]. Qiu et al. found that miR-143 and miR-124 were upregulated in the mouse OA model after treatment of EVs derived from curcumin-treated MSC, and the normal expression of NF-kB and Rho-associated coiled-coil containing protein kinase 1 (ROCK1) was significantly restored, resulting in weakened progression of OA [55]. Studies have shown that EVs isolated from rabbit subpatellar fat pad mesenchymal stem cells pretreated with Kartogenin (KGN) have the effective ability to induce chondrogenic differentiation of stem cells, effectively promote the proliferation and expression of chondrogenic proteins and genes of chondrocytes, and are more effective to promote the repair of articular cartilage defects [56]. Similarly, EVs derived from KGN pretreated SD rat BMSC are more effective than EVs derived from BMSC in cartilage repair [57]. Jing et al. evaluated the regenerative potential of sEVs from human umbilical cord mesenchymal stem cells (hUCMSCs) pretreated with KGN to induce cartilage differentiation of MSCs, which was mainly achieved by providing sEV-miR-381-3p targeting thousand and one kinase 1 (TAOK1) [58].

\subsection{Biological Factors}

Wang et al. found that TGF- $\beta 1$ stimulation can upregulate the expression of miR-135b in MSC-EVs, and delivering TGF- $\beta 1$ pretreated MSC-EVs to chondrocytes can downregulate Sp1 to promote chondrocyte proliferation, thereby promoting cartilage repair in OA [59]. They also found that MSC-EVs pretreated with TGF- $\beta 1$ can reduce the upregulation of pro-inflammatory factors in the serum of OA rats and the damage of cartilage tissue through miR-135b that target MAPK6 to promote the M2 polarization of synovial macrophages [59]. There are also studies on directly modifying EVs with biological factors for OA treatment. Activated transcription factor 4 (ATF4) is essential for chondrocyte proliferation and bone formation. Wang et al. introduced ATF4 mRNA into serum-derived EVs from OA mice (OA-EVs) by electroporation, and found ATF4-modified OA-EVs can protect cartilage and alleviate OA progression by inducing autophagy [60]. 


\subsection{Genetic Modification}

It is well known that non-coding RNA (microRNA [miRNA] and long-chain noncoding RNA [lncRNA]) is currently one of the most studied molecules in EV research. Qiu et al. found that MSC-EVs overexpressing miR-129-5p inhibited IL-1 $\beta$-mediated upregulation of HMGB1 and significantly reduced the inflammation and apoptosis of chondrocytes [61]. EVs of synovial mesenchymal stem cells (SMSCs) overexpressing miR-140-5p (SMSC-140-EVs) enhanced the proliferation and migration of chondrocytes in vitro without destroying the secretion of ECM, while in vivo, SMSC-140-EVs successfully prevented OA in the rat model [62]. EVs from human MSCs overexpressing miR-92a-3p enhanced cartilage formation and inhibited cartilage degradation by targeting WNT5A [63]. EVs from SMSCs overexpressing miR-155-5p prevented osteoarthritis by enhancing proliferation and migration, reducing cell apoptosis, and regulating extracellular matrix secretion in chondrocytes [64]. EVs from synovial fibroblasts overexpressing miR-126-3p inhibited chondrocyte inflammation and cartilage degradation in a rat model of OA [65]. MiR-26a$5 p$-overexpressed HBMSC-derived EVs delayed the damage of synovial fibroblasts in vitro and reduced OA damage in vivo [66]. Mao et al. found that the expression of miR-95-5p in EVs secreted by OA chondrocytes was significantly lower than that of normal cartilage and EVs derived from primary chondrocytes overexpressing miR-95-5p (AC-miR-95-5p-EVs) could enhance cartilage formation and prevent the development of $\mathrm{OA}$ by directly targeting HDAC2/8 [67].

Liu et al. found that transplantation of EVs secreted by stem cells overexpressing the novel lncRNA KLF3 Antisense RNA 1 (lncRNA KLF3-AS1) could promote cartilage repair by promoting chondrocyte proliferation and inhibiting cell apoptosis through the miR-206/GIT1 axis, emphasizing the possible mechanism of OA treatment through cellular delivery of lncRNA KLF3-AS1 [68]. Tan et al. found that fibroblast-like synoviocytes overexpressing LncRNA H19 (FLS-LncRNA H19) had a positive effect on reversing IL-1 $\beta$-induced chondrocyte damage. FLS-LncRNA H19-derived EVs can promote cell viability and migration, and prevent IL-1- $\beta$-induced ECM degradation in chondrocytes by regulating the expression of miR-106b-5p and Tissue inhibitor of metalloproteinases 2 (TIMP2) [69].

\subsection{Hypoxia}

The oxygen content of the physiological environment in vivo is very different from the oxygen content observed in the growth medium $\left(21 \% \mathrm{O}_{2}\right.$ in normoxia). Therefore, the experimental parameters in vitro may not be able to simulate the real microenvironment in vivo. However, the function of hypoxia in EVs is controversial with evidence showing the adverse effects of EVs after hypoxia. Ding et al. found that EVs secreted during hypoxia in synovial fibroblasts (SFs) aggravated rheumatoid arthritis by regulating Treg/Th17 balance [70]. However, research by Hu et al. showed that when cells were cultured at an oxygen concentration lower than $0.5 \%$, hypoxic pretreatment (HP) increased MSC migration and reduced MSC apoptosis [71]. In terms of OA and cartilage repair, in rabbit knee joint trauma and focal early OA models, aerobic MSC treatment significantly improved cartilage repair scores compared with hyperoxic MSC and their respective control defects [72]. Rong et al. found that EVs derived from BMSCs treated with hypoxia-inducible factor $1 \alpha$-induced hypoxic can promote chondrocyte proliferation, migration, and inhibit apoptosis through the miR-216a-5p/JAK2/STAT3 signaling pathway as well as mediate cartilage repair in osteoarthritis [73].

\section{EV Delivery Biomaterials}

The progress of OA has complicated the delivery of EVs in the joint cavity. However, regardless of the inflammation state of the joint, $300 \mathrm{~nm}$ nanoparticles can quickly escape from the joint space [74]. Unfortunately, some of the EVs (such as exosomes) are less than $300 \mathrm{~nm}$, which are difficult to keep in the joint space for a long time. Therefore, it is crucial to develop an intra-articular injection device for the controlled release of EVs. 
Yang et al. developed a Diels-Alder crosslinked hyaluronic acid (HA)/polyethylene glycol (PEG) hydrogel (DAHP) for intraarticular MSC-EV delivery. Through the controlled release, the effect of EVs in improving OA was enhanced, and the average OARSI score of the EV-loaded DAHP hydrogel-treated group was low, which showed no significant difference to that of the multiple EV injection group, but was lower than that of the single EV injection group, the DAHP hydrogel group, and the saline group [75]. Liu et al. developed a photoimine cross-linked hydrogel as an EV scaffold for cartilage regeneration, while most of the encapsulated EVs can still be retained in the hydrogel (>90\%) after being immersed in PBS for 14 days. The controlled release system had active cell regulation in vitro and in vivo, and promoted cartilage repair and regeneration [76]. Chen et al. used desktop stereolithography to fabricate a 3D printed cartilage extracellular matrix (ECM)/gelatin methacrylate (GelMA)/EV scaffold with radially oriented channels. The scaffold can continuously release EVs for at least 14 days in vitro, and retain EVs in vivo for at least seven days [77]. Hu et al. prepared a GelMA/nanoclay/EV hydrogel. EVs were released in a sustained manner as the hydrogel degraded, achieving successful cartilage regeneration, exhibiting intact and smooth regenerated neotissue, which were well integrated with the surrounding original cartilage and similar to the normal cartilage [78]. Tao et al. used the thermosensitive hydrogel PDLLA-PEG-PDLLA triblock copolymer gel to show good performance in sustained-release EVs. Compared with the direct injection of EVs, it had better long-term effects on the protection of cartilage and delaying the progression of OA [79].

\section{Engineered EV Strategy}

The use of engineered strategies to improve EVs has been extensively studied in the field of oncology (such as prostate cancer [80], breast cancer [81]) and rheumatoid arthritis [82]. The strategy has gradually received attention in the treatment of $\mathrm{OA} /$ cartilage injury.

The densely packed collagen and proteoglycan and highly negatively charged glycosaminoglycan in the joint tissue form a barrier for the drug to reach the chondrocytes, which makes cartilage cell targeted drug delivery a daunting task. Liang et al. fused the lysosomal-associated membrane protein 2 (LAMP-2B) gene with chondrocyte affinity peptide (CAP) and transfected it into dendritic cells to generate EVs that target chondrocytes, and miR-140 was delivered to chondrocytes in the deep area of cartilage to extend retention in the cartilage area and induce cartilage repair [83]. Xu et al. fused the MSC-binding peptide E7 with the EV membrane protein Lamp $2 b$ to produce EVs with E7 peptides (E7-EVs) with synovial fluid mesenchymal stem cell (SF-MSC) targeting ability. Compared with KGN delivered alone or by EVs without E7, KGN delivered by E7-EVs effectively enters SF-MSC and induces a higher degree of cartilage differentiation, which is expected to become an advanced stem cell therapy for OA [84].

\section{Conclusions}

EVs are natural nanoparticles containing proteins, mRNA, miRNA, LncRNA, and lipids, which participate in the communication between cells. In recent years, they have received more and more attention in the OA field. EVs from different cell sources not only participate in the progress of OA, but can also be used as an effective tool for the diagnosis and treatment of OA. In addition, the development of cell pretreatment strategies and tissue engineering technology has achieved encouraging results as summarized in Figure 1, where EVs may open up new strategies for the treatment of OA. 


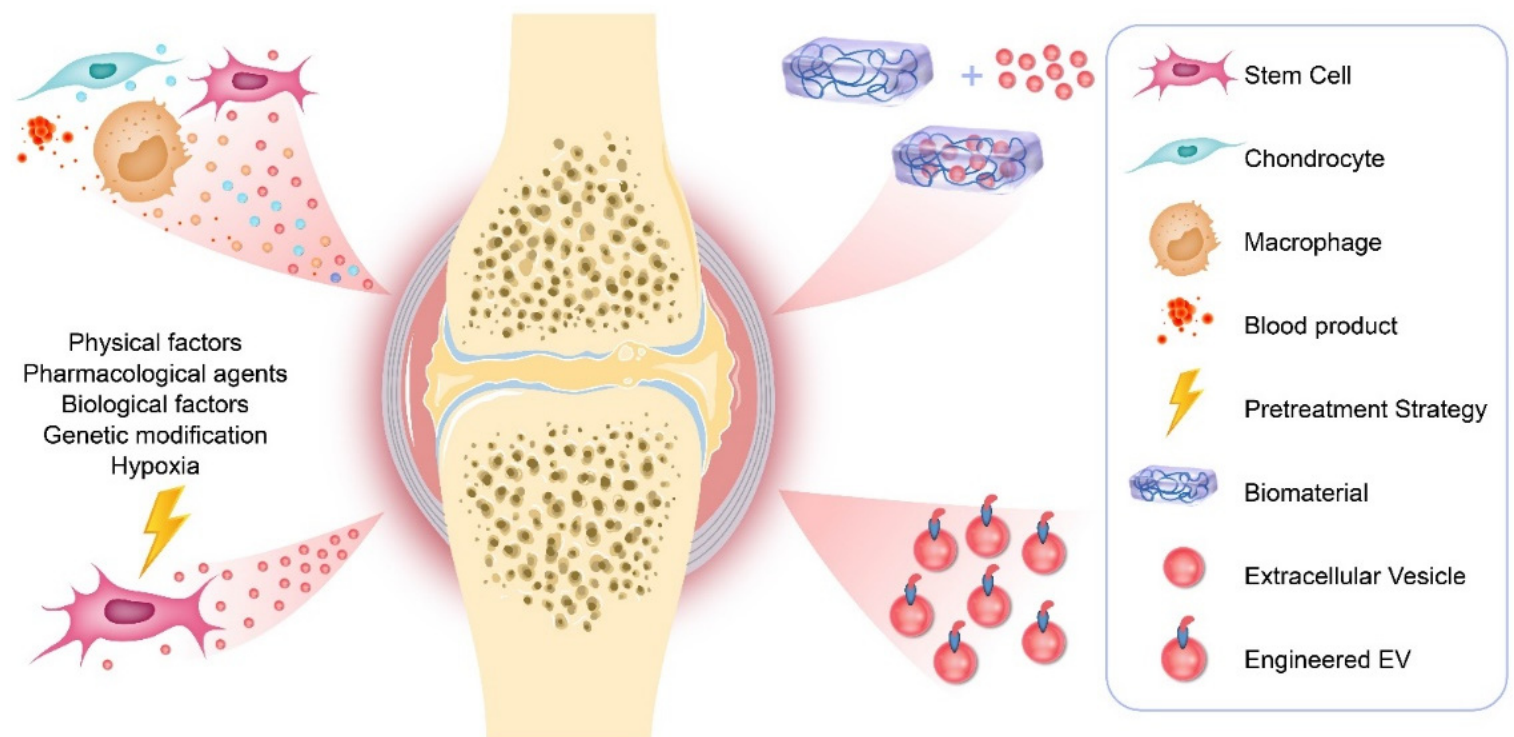

Figure 1. Therapeutic applications of EVs in OA.

Author Contributions: J.L. (Jianjing Lin) and L.W. both participated in the drafting of the manuscript unanimously. J.L. (Jianhao Lin) and Q.L. reviewed and revised the manuscript. All authors have read and agreed to the published version of the manuscript.

Funding: This study was funded by grants from the National Natural Science Foundation of China [81902247] and National Key R\&D Program (2020YFC2004904).

Institutional Review Board Statement: Not applicable.

Informed Consent Statement: Not applicable.

Data Availability Statement: Not applicable.

Conflicts of Interest: The authors declare that they have no competing interest.

\section{References}

1. Hunter, D.J.; Bierma-Zeinstra, S. Osteoarthritis. Lancet 2019, 393, 1745-1759. [CrossRef]

2. Sharma, L. Osteoarthritis of the Knee. N. Engl. J. Med. 2021, 384, 51-59. [CrossRef]

3. Hunter, D.J.; March, L.; Chew, M. Osteoarthritis in 2020 and beyond: A Lancet Commission. Lancet 2020, 396, 1711-1712. [CrossRef]

4. Burand, A.J.; Gramlich, O.W.; Brown, A.J.; Ankrum, J.A. Function of Cryopreserved Mesenchymal Stromal Cells with and without Interferon- $\gamma$ Prelicensing is Context Dependent. Stem Cells 2017, 35, 1437-1439. [CrossRef] [PubMed]

5. Castellone, M.D.; Laatikainen, L.E.; Laurila, J.P.; Langella, A.; Hematti, P.; Soricelli, A.; Salvatore, M.; Laukkanen, M. Brief Report: Mesenchymal Stromal Cell Atrophy in Coculture Increases Aggressiveness of Transformed Cells. Stem Cells 2013, 31, 1218-1223. [CrossRef] [PubMed]

6. Ryan, S.T.; Hosseini-Beheshti, E.; Afrose, D.; Ding, X.; Xia, B.; Grau, G.; Little, C.; McClements, L.; Li, J. Extracellular Vesicles from Mesenchymal Stromal Cells for the Treatment of Inflammation-Related Conditions. Int. J. Mol. Sci. 2021, 22, 3023. [CrossRef]

7. Théry, C.; Witwer, K.W.; Aikawa, E.; Alcaraz, M.J.; Anderson, J.D.; Andriantsitohaina, R.; Antoniou, A.; Arab, T.; Archer, F.; Atkin-Smith, G.K.; et al. Minimal information for studies of extracellular vesicles 2018 (MISEV2018): A position statement of the International Society for Extracellular Vesicles and update of the MISEV2014 guidelines. J. Extracell. Vesicles 2018, 7, 1535750. [CrossRef]

8. Ni, Z.; Zhou, S.; Li, S.; Kuang, L.; Chen, H.; Luo, X.; Ouyang, J.; He, M.; Du, X.; Chen, L. Exosomes: Roles and therapeutic potential in osteoarthritis. Bone Res. 2020, 8, 25. [CrossRef] [PubMed]

9. Samavedi, S.; Diaz-Rodriguez, P.; Erndt-Marino, J.D.; Hahn, M.S. A Three-Dimensional Chondrocyte-Macrophage Coculture System to Probe Inflammation in Experimental Osteoarthritis. Tissue Eng. Part A 2017, 23, 101-114. [CrossRef] [PubMed]

10. Peng, S.; Yan, Y.; Li, R.; Dai, H.; Xu, J. Extracellular vesicles from M1-polarized macrophages promote inflammation in the temporomandibular joint via miR-1246 activation of the Wnt/ $\beta$-catenin pathway. Ann. N. Y. Acad. Sci. 2021. [CrossRef] 
11. Domenis, R.; Zanutel, R.; Caponnetto, F.; Toffoletto, B.; Cifù, A.; Pistis, C.; Di Benedetto, P.; Causero, A.; Pozzi, M.; Bassini, F.; et al. Characterization of the Proinflammatory Profile of Synovial Fluid-Derived Exosomes of Patients with Osteoarthritis. Mediat. Inflamm. 2017, 2017, 4814987. [CrossRef] [PubMed]

12. Gao, K.; Zhu, W.; Li, H.; Ma, D.; Liu, W.; Yu, W.; Wang, L.; Cao, Y.; Jiang, Y. Association between cytokines and exosomes in synovial fluid of individuals with knee osteoarthritis. Mod. Rheumatol. 2020, 30, 758-764. [CrossRef] [PubMed]

13. Yang, R.-Z.; Zheng, H.-L.; Xu, W.-N.; Zheng, X.-F.; Li, B.; Jiang, L.-S.; Jiang, S.-D. Vascular endothelial cell-secreted exosomes facilitate osteoarthritis pathogenesis by promoting chondrocyte apoptosis. Aging 2021, 13, 4647-4662. [CrossRef]

14. Wu, X.; Crawford, R.; Xiao, Y.; Mao, X.; Prasadam, I. Osteoarthritic Subchondral Bone Release Exosomes That Promote Cartilage Degeneration. Cells 2021, 10, 251. [CrossRef] [PubMed]

15. Jeon, O.H.; Wilson, D.R.; Clement, C.C.; Rathod, S.; Cherry, C.; Powell, B.; Lee, Z.; Khalil, A.M.; Green, J.J.; Campisi, J.; et al. Senescence cell-associated extracellular vesicles serve as osteoarthritis disease and therapeutic markers. JCI Insight 2019, 4. [CrossRef]

16. Ni, Z.; Kuang, L.; Chen, H.; Xie, Y.; Zhang, B.; Ouyang, J.; Wu, J.; Zhou, S.; Chen, L.; Su, N.; et al. The exosome-like vesicles from osteoarthritic chondrocyte enhanced mature IL-1 $\beta$ production of macrophages and aggravated synovitis in osteoarthritis. Cell Death Dis. 2019, 10, 522. [CrossRef] [PubMed]

17. Kolhe, R.; Hunter, M.; Liu, S.; Jadeja, R.N.; Pundkar, C.; Mondal, A.K.; Mendhe, B.; Drewry, M.; Rojiani, M.V.; Liu, Y.; et al. Gender-specific differential expression of exosomal miRNA in synovial fluid of patients with osteoarthritis. Sci. Rep. 2017, 7, 2029. [CrossRef]

18. Kolhe, R.; Owens, V.; Sharma, A.; Lee, T.J.; Zhi, W.; Ghilzai, U.; Mondal, A.K.; Liu, Y.; Isales, C.M.; Hamrick, M.W.; et al. Sex-Specific Differences in Extracellular Vesicle Protein Cargo in Synovial Fluid of Patients with Osteoarthritis. Life 2020, 10, 337. [CrossRef]

19. Bhattacharya, I.; Saxena, R.; Gupta, V. Efficacy of vitamin E in knee osteoarthritis management of North Indian geriatric population. Ther. Adv. Musculoskelet. Dis. 2012, 4, 11-19. [CrossRef]

20. Wu, B.J.; Ong, K.L.; Shrestha, S.; Chen, K.; Tabet, F.; Barter, P.J.; Rye, K.-A. Inhibition of Arthritis in the Lewis Rat by Apolipoprotein A-I and Reconstituted High-Density Lipoproteins. Arter. Thromb. Vasc. Biol. 2014, 34, 543-551. [CrossRef]

21. Mustonen, A.-M.; Capra, J.; Rilla, K.; Lehenkari, P.; Oikari, S.; Kääriäinen, T.; Joukainen, A.; Kröger, H.; Paakkonen, T.; Matilainen, J.; et al. Characterization of hyaluronan-coated extracellular vesicles in synovial fluid of patients with osteoarthritis and rheumatoid arthritis. BMC Musculoskelet. Disord. 2021, 22, 247. [CrossRef]

22. Zhao, Y.; Xu, J. Synovial fluid-derived exosomal lncRNA PCGEM1 as biomarker for the different stages of osteoarthritis. Int. Orthop. 2018, 42, 2865-2872. [CrossRef] [PubMed]

23. Meng, Y.; Qiu, S.; Sun, L.; Zuo, J. Knockdown of exosome-mediated lnc-PVT1 alleviates lipopolysaccharide-induced osteoarthritis progression by mediating the HMGB1/TLR4/NF-kB pathway via miR-93-5p. Mol. Med. Rep. 2020, 22, 5313-5325. [CrossRef] [PubMed]

24. Meng, F.; Li, Z.; Zhang, Z.; Yang, Z.; Kang, Y.; Zhao, X.; Long, D.; Hu, S.; Gu, M.; He, S.; et al. MicroRNA-193b-3p regulates chondrogenesis and chondrocyte metabolism by targeting HDAC3. Theranostics 2018, 8, 2862-2883. [CrossRef]

25. Vonk, L.A.; Van Dooremalen, S.F.J.; Liv, N.; Klumperman, J.; Coffer, P.J.; Saris, D.B.; Lorenowicz, M.J. Mesenchymal Stromal/stem Cell-derived Extracellular Vesicles Promote Human Cartilage Regeneration In Vitro. Theranostics 2018, 8, 906-920. [CrossRef] [PubMed]

26. He, L.; He, T.; Xing, J.; Zhou, Q.; Fan, L.; Liu, C.; Chen, Y.; Wu, D.; Tian, Z.; Liu, B.; et al. Bone marrow mesenchymal stem cell-derived exosomes protect cartilage damage and relieve knee osteoarthritis pain in a rat model of osteoarthritis. Stem Cell Res. Ther. 2020, 11, 276. [CrossRef]

27. Li, S.; Stöckl, S.; Lukas, C.; Gtz, J.; Grssel, S. hBMSC-Derived Extracellular Vesicles Attenuate IL-1 $\beta$-Induced Catabolic Effects on OA-Chondrocytes by Regulating Pro-inflammatory Signaling Pathways. Front. Bioeng. Biotechnol. 2020, 8, 603598. [CrossRef]

28. Qi, H.; Liu, D.-P.; Xiao, D.-W.; Tian, D.-C.; Su, Y.-W.; Jin, S.-F. Exosomes derived from mesenchymal stem cells inhibit mitochondrial dysfunction-induced apoptosis of chondrocytes via p38, ERK, and Akt pathways. Vitr. Cell. Dev. Biol. Anim. 2019, 55, 203-210. [CrossRef]

29. Chen, X.; Shi, Y.; Xue, P.; Ma, X.; Li, J.; Zhang, J. Mesenchymal stem cell-derived exosomal microRNA-136-5p inhibits chondrocyte degeneration in traumatic osteoarthritis by targeting ELF3. Arthritis Res. Ther. 2020, 22, 256. [CrossRef]

30. Zhang, J.; Rong, Y.; Luo, C.; Cui, W. Bone marrow mesenchymal stem cell-derived exosomes prevent osteoarthritis by regulating synovial macrophage polarization. Aging 2020, 12, 25138-25152. [CrossRef]

31. Li, J.; Ding, Z.; Li, Y.; Wang, W.; Wang, J.; Yu, H.; Liu, A.; Miao, J.; Chen, S.; Wu, T.; et al. BMSCs-Derived Exosomes Ameliorate Pain Via Abrogation of Aberrant Nerve Invasion in Subchondral Bone in Lumbar Facet Joint Osteoarthritis. J. Orthop. Res. 2020, 38, 670-679. [CrossRef]

32. Zhou, X.; Liang, H.; Hu, X.; An, J.; Ding, S.; Yu, S.; Liu, C.; Li, F.; Xu, Y. BMSC-derived exosomes from congenital polydactyly tissue alleviate osteoarthritis by promoting chondrocyte proliferation. Cell Death Discov. 2020, 6, 142. [CrossRef] [PubMed]

33. Wu, J.; Kuang, L.; Chen, C.; Yang, J.; Zeng, W.-N.; Li, T.; Chen, H.; Huang, S.; Fu, Z.; Li, J.; et al. miR-100-5p-abundant exosomes derived from infrapatellar fat pad MSCs protect articular cartilage and ameliorate gait abnormalities via inhibition of mTOR in osteoarthritis. Biomaterials 2019, 206, 87-100. [CrossRef] [PubMed] 
34. Cavallo, C.; Merli, G.; Borzì, R.M.; Zini, N.; D’Adamo, S.; Guescini, M.; Grigolo, B.; Di Martino, A.; Santi, S.; Filardo, G.; et al. Small Extracellular Vesicles from adipose derived stromal cells significantly attenuate in vitro the NF- $\kappa B$ dependent inflammatory/catabolic environment of osteoarthritis. Sci. Rep. 2021, 11, 1053. [CrossRef] [PubMed]

35. Woo, C.H.; Kim, H.K.; Yang, S.; Park, J.H.; Jo, D.; Cho, Y.W.; Jung, G.Y.; Jung, Y.J.; Lee, K.S.; Yun, Y.E.; et al. Small extracellular vesicles from human adipose-derived stem cells attenuate cartilage degeneration. J. Extracell. Vesicles 2020, 9, 1735249. [CrossRef]

36. Tofiño-Vian, M.; Guillén, M.I.; del Caz, M.D.P.; Castejón, M.A.; Alcaraz, M.J. Extracellular Vesicles from Adipose-Derived Mesenchymal Stem Cells Downregulate Senescence Features in Osteoarthritic Osteoblasts. Oxidative Med. Cell. Longev. 2017, 2017, 7197598. [CrossRef]

37. Zhao, C.; Chen, J.Y.; Peng, W.M.; Yuan, B.; Bi, Q.; Xu, Y.J. Exosomes from adipose-derived stem cells promote chondrogenesis and suppress inflammation by upregulating miR-145 and miR-221. Mol. Med. Rep. 2020, 21, 1881-1889. [CrossRef]

38. Zhang, S.; Chu, W.C.; Lai, R.C.; Lim, S.K.; Hui, J.H.P.; Toh, W.S. Exosomes derived from human embryonic mesenchymal stem cells promote osteochondral regeneration. Osteoarthr. Cartil. 2016, 24, 2135-2140. [CrossRef]

39. Wang, Y.; Yu, D.; Liu, Z.; Zhou, F.; Dai, J.; Wu, B.; Zhou, J.; Heng, B.C.; Zou, X.H.; Ouyang, H. Exosomes from embryonic mesenchymal stem cells alleviate osteoarthritis through balancing synthesis and degradation of cartilage extracellular matrix. Stem Cell Res Ther. 2017, 8, 189. [CrossRef]

40. Zhang, S.; Teo, K.Y.W.; Chuah, S.J.; Lai, R.C.; Lim, S.K.; Toh, W.S. MSC exosomes alleviate temporomandibular joint osteoarthritis by attenuating inflammation and restoring matrix homeostasis. Biomaterials 2019, 200, 35-47. [CrossRef]

41. Ragni, E.; Papait, A.; Orfei, C.P.; Silini, A.R.; Colombini, A.; Viganò, M.; Libonati, F.; Parolini, O.; de Girolamo, L. Amniotic membrane-mesenchymal stromal cells secreted factors and extracellular vesicle -miRNAs: Anti-inflammatory and regenerative features for musculoskeletal tissues. Stem Cells Transl. Med. 2021, 10, 1044-1062. [CrossRef] [PubMed]

42. Wang, K.; Li, F.; Yuan, Y.; Shan, L.; Cui, Y.; Qu, J.; Lian, F. Synovial Mesenchymal Stem Cell-Derived EV-Packaged miR-31 Downregulates Histone Demethylase KDM2A to Prevent Knee Osteoarthritis. Mol. Ther. Nucleic Acids 2020, 22, $1078-1091$. [CrossRef]

43. Zhu, Y.; Wang, Y.; Zhao, B.; Niu, X.; Hu, B.; Li, Q.; Zhang, J.; Ding, J.; Chen, Y.; Wang, Y. Comparison of exosomes secreted by induced pluripotent stem cell-derived mesenchymal stem cells and synovial membrane-derived mesenchymal stem cells for the treatment of osteoarthritis. Stem Cell Res. Ther. 2017, 8, 64. [CrossRef]

44. Luo, P.; Jiang, C.; Ji, P.; Wang, M.; Xu, J. Exosomes of stem cells from human exfoliated deciduous teeth as an anti-inflammatory agent in temporomandibular joint chondrocytes via miR-100-5p/mTOR. Stem Cell Res. Ther. 2019, 10, 216. [CrossRef]

45. Zheng, L.; Wang, Y.; Qiu, P.; Xia, C.; Fang, Y.; Mei, S.; Fang, C.; Shi, Y.; Wu, K.; Chen, Z.; et al. Primary chondrocyte exosomes mediate osteoarthritis progression by regulating mitochondrion and immune reactivity. Nanomedicine 2019, 14, $3193-3212$. [CrossRef]

46. Bai, J.; Zhang, Y.; Zheng, X.; Huang, M.; Cheng, W.; Shan, H.; Gao, X.; Zhang, M.; Sheng, L.; Dai, J.; et al. LncRNA MM2P-induced, exosome-mediated transfer of Sox 9 from monocyte-derived cells modulates primary chondrocytes. Cell Death Dis. 2020, 11, 76 [CrossRef] [PubMed]

47. Gato-Calvo, L.; Magalhães, J.; Ruiz-Romero, C.; Blanco, F.J.; Burguera, E.F. Platelet-rich plasma in osteoarthritis treatment: Review of current evidence. Ther. Adv. Chronic Dis. 2019, 10. [CrossRef]

48. Otahal, A.; Kramer, K.; Kuten-Pella, O.; Weiss, R.; Stotter, C.; Lacza, Z.; Weber, V.; Nehrer, S.; De Luna, A. Characterization and Chondroprotective Effects of Extracellular Vesicles From Plasma- and Serum-Based Autologous Blood-Derived Products for Osteoarthritis Therapy. Front. Bioeng. Biotechnol. 2020, 8, 584050. [CrossRef] [PubMed]

49. Liu, X.; Wang, L.; Ma, C.; Wang, G.; Zhang, Y.; Sun, S. Exosomes derived from platelet-rich plasma present a novel potential in alleviating knee osteoarthritis by promoting proliferation and inhibiting apoptosis of chondrocyte via Wnt/ $\beta$-catenin signaling pathway. J. Orthop. Surg. Res. 2019, 14, 470. [CrossRef]

50. Jiang, S.; Tian, G.; Li, X.; Yang, Z.; Wang, F.; Tian, Z.; Huang, B.; Wei, F.; Zha, K.; Sun, Z.; et al. Research Progress on Stem Cell Therapies for Articular Cartilage Regeneration. Stem Cells Int. 2021, 2021, 8882505. [CrossRef]

51. Xia, P.; Wang, X.; Qu, Y.; Lin, Q.; Cheng, K.; Gao, M.; Ren, S.; Zhang, T.; Li, X. TGF- $\beta 1$-induced chondrogenesis of bone marrow mesenchymal stem cells is promoted by low-intensity pulsed ultrasound through the integrin-mTOR signaling pathway. Stem Cell Res. Ther. 2017, 8, 281. [CrossRef]

52. Wang, X.; Lin, Q.; Zhang, T.; Wang, X.; Cheng, K.; Gao, M.; Xia, P.; Li, X. Low-intensity pulsed ultrasound promotes chondrogenesis of mesenchymal stem cells via regulation of autophagy. Stem Cell Res. Ther. 2019, 10, 41. [CrossRef]

53. Liao, Q.; Li, B.J.; Li, Y.; Xiao, Y.; Zeng, H.; Liu, M.J.; Yuan, L.X.; Liu, G. Low-intensity pulsed ultrasound promotes osteoarthritic cartilage regeneration by BMSC-derived exosomes via modulating the NF-kB signaling pathway. Int. Immunopharmacol. 2021, 97, 107824. [CrossRef]

54. Li, S.; Stöckl, S.; Lukas, C.; Herrmann, M.; Brochhausen, C.; König, M.A.; Johnstone, B.; Grässel, S. Curcumin-primed human BMSC-derived extracellular vesicles reverse IL-1 $\beta$-induced catabolic responses of OA chondrocytes by upregulating miR-126-3p. Stem Cell Res. Ther. 2021, 12, 252. [CrossRef] [PubMed]

55. Qiu, B.; Xu, X.; Yi, P.; Hao, Y. Curcumin reinforces MSC-derived exosomes in attenuating osteoarthritis via modulating the miR-124/NF-kB and miR-143/ROCK1/TLR9 signalling pathways. J.Cell. Mol. Med. 2020, 24, 10855-10865. [CrossRef] [PubMed] 
56. Shao, J.; Zhu, J.; Chen, Y.; Fu, Q.; Li, L.; Ding, Z.; Wu, J.; Han, Y.; Li, H.; Qian, Q.; et al. Exosomes from Kartogenin-Pretreated Infrapatellar Fat Pad Mesenchymal Stem Cells Enhance Chondrocyte Anabolism and Articular Cartilage Regeneration. Stem Cells Int. 2021, 2021, 6624874. [CrossRef] [PubMed]

57. Liu, C.; Li, Y.; Yang, Z.; Zhou, Z.; Lou, Z.; Zhang, Q. Kartogenin enhances the therapeutic effect of bone marrow mesenchymal stem cells derived exosomes in cartilage repair. Nanomedicine 2020, 15, 273-288. [CrossRef]

58. Jing, H.; Zhang, X.; Luo, K.; Luo, Q.; Yin, M.; Wang, W.; Zhu, Z.; Zheng, J.; He, X. miR-381-abundant small extracellular vesicles derived from kartogenin-preconditioned mesenchymal stem cells promote chondrogenesis of MSCs by targeting TAOK1. Biomaterials 2020, 231, 119682. [CrossRef]

59. Wang, R.; Xu, B. TGF- $\beta 1$-modified MSC-derived exosomal miR-135b attenuates cartilage injury via promoting M2 synovial macrophage polarization by targeting MAPK6. Cell Tissue Res. 2021, 384, 113-127. [CrossRef]

60. Wang, Y.; He, S.; Liang, X.; Zhang, X.; Li, S.; Li, T. ATF4 -modified serum exosomes derived from osteoarthritic mice inhibit osteoarthritis by inducing autophagy. IUBMB Life 2021, 73, 146-158. [CrossRef]

61. Qiu, M.; Liu, D.; Fu, Q. MiR-129-5p shuttled by human synovial mesenchymal stem cell-derived exosomes relieves IL-1 $\beta$ induced osteoarthritis via targeting HMGB1. Life Sci. 2021, 269, 118987. [CrossRef]

62. Tao, S.-C.; Yuan, T.; Zhang, Y.-L.; Yin, W.-J.; Guo, S.-C.; Zhang, C.-Q. Exosomes derived from miR-140-5p-overexpressing human synovial mesenchymal stem cells enhance cartilage tissue regeneration and prevent osteoarthritis of the knee in a rat model. Theranostics 2017, 7, 180-195. [CrossRef]

63. Mao, G.; Zhang, Z.; Hu, S.; Zhang, Z.; Chang, Z.; Huang, Z.; Liao, W.; Kang, Y. Exosomes derived from miR-92a-3p-overexpressing human mesenchymal stem cells enhance chondrogenesis and suppress cartilage degradation via targeting WNT5A. Stem Cell Res. Ther. 2018, 9, 247. [CrossRef]

64. Wang, Z.; Yan, K.; Ge, G.; Zhang, D.; Bai, J.; Guo, X.; Zhou, J.; Xu, T.; Xu, M.; Long, X.; et al. Exosomes derived from miR-155-5poverexpressing synovial mesenchymal stem cells prevent osteoarthritis via enhancing proliferation and migration, attenuating apoptosis, and modulating extracellular matrix secretion in chondrocytes. Cell Biol. Toxicol. 2021, 37, 85-96. [CrossRef]

65. Zhou, Y.; Ming, J.; Li, Y.; Li, B.; Deng, M.; Ma, Y.; Chen, Z.; Zhang, Y.; Li, J.; Liu, S. Exosomes derived from miR-126-3poverexpressing synovial fibroblasts suppress chondrocyte inflammation and cartilage degradation in a rat model of osteoarthritis. Cell Death Discov. 2021, 7, 37. [CrossRef]

66. Jin, Z.; Ren, J.; Qi, S. Human bone mesenchymal stem cells-derived exosomes overexpressing microRNA-26a-5p alleviate osteoarthritis via down-regulation of PTGS2. Int. Immunopharmacol. 2020, 78, 105946. [CrossRef] [PubMed]

67. Mao, G.; Hu, S.; Zhang, Z.; Wu, P.; Zhao, X.; Lin, R.; Liao, W.; Kanget, Y. Exosomal miR-95-5p regulates chondrogenesis and cartilage degradation via histone deacetylase 2/8. J. Cell. Mol. Med. 2018, 22, 5354-5366. [CrossRef] [PubMed]

68. Liu, Y.; Lin, L.; Zou, R.; Wen, C.; Wang, Z.; Lin, F. MSC-derived exosomes promote proliferation and inhibit apoptosis of chondrocytes via lncRNA-KLF3-AS1/miR-206/GIT1 axis in osteoarthritis. Cell Cycle 2018, 17, 2411-2422. [CrossRef] [PubMed]

69. Tan, F.; Wang, D.; Yuan, Z. The Fibroblast-Like Synoviocyte Derived Exosomal Long Non-coding RNA H19 Alleviates Osteoarthritis Progression Through the miR-106b-5p/TIMP2 Axis. Inflammation 2020, 43, 1498-1509. [CrossRef]

70. Ding, Y.; Wang, L.; Wu, H.; Zhao, Q.; Wu, S. Exosomes derived from synovial fibroblasts under hypoxia aggravate rheumatoid arthritis by regulating Treg/Th17 balance. Exp. Biol. Med. 2020, 245, 1177-1186. [CrossRef]

71. Hu, X.; Xu, Y.; Zhong, Z.; Wu, Y.; Zhao, J.; Wang, Y.; Cheng, H.; Kong, M.; Zhang, F.; Chen, Q.; et al. A Large-Scale Investigation of Hypoxia-Preconditioned Allogeneic Mesenchymal Stem Cells for Myocardial Repair in Nonhuman Primates: Paracrine Activity Without Remuscularization. Circ. Res. 2016, 118, 970-983. [CrossRef] [PubMed]

72. Pattappa, G.; Krueckel, J.; Schewior, R.; Franke, D.; Mench, A.; Koch, M.; Weber, J.; Lang, S.; Pfeifer, C.G.; Johnstone, B.; et al. Physioxia Expanded Bone Marrow Derived Mesenchymal Stem Cells Have Improved Cartilage Repair in an Early Osteoarthritic Focal Defect Model. Biology 2020, 9, 230. [CrossRef] [PubMed]

73. Rong, Y.; Zhang, J.; Jiang, D.; Ji, C.; Liu, W.; Wang, J.; Ge, X.; Tang, P.; Yu, S.; Cui, W.; et al. Hypoxic pretreatment of small extracellular vesicles mediates cartilage repair in osteoarthritis by delivering miR-216a-5p. Acta Biomater. 2021, 122, 325-342. [CrossRef] [PubMed]

74. Pradal, J.; Maudens, P.; Gabay, C.; Seemayer, C.A.; Jordan, O.; Allémann, E. Effect of particle size on the biodistribution of nanoand microparticles following intra-articular injection in mice. Int. J. Pharm. 2016, 498, 119-129. [CrossRef] [PubMed]

75. Yang, Y.; Zhu, Z.; Gao, R.; Yuan, J.; Zhang, J.; Li, H.; Xie, Z.; Wang, Y. Controlled release of MSC-derived small extracellular vesicles by an injectable Diels-Alder crosslinked hyaluronic acid/PEG hydrogel for osteoarthritis improvement. Acta Biomater. 2021, 128, 163-174. [CrossRef]

76. Liu, X.; Yang, Y.; Li, Y.; Niu, X.; Zhao, B.; Wang, Y.; Bao, C.; Xie, Z.; Lin, Q.; Zhu, L. Integration of stem cell-derived exosomes with in situ hydrogel glue as a promising tissue patch for articular cartilage regeneration. Nanoscale 2017, 9, 4430-4438. [CrossRef]

77. Chen, P.; Zheng, L.; Wang, Y.; Tao, M.; Xie, Z.; Xia, C.; Gu, C.; Chen, J.; Qiu, P.; Mei, S.; et al. Desktop-stereolithography 3D printing of a radially oriented extracellular matrix/mesenchymal stem cell exosome bioink for osteochondral defect regeneration. Theranostics 2019, 9, 2439-2459. [CrossRef]

78. Hu, H.; Dong, L.; Bu, Z.; Shen, Y.; Luo, J.; Zhang, H.; Zhao, S.; Lv, F.; Liu, Z. miR-23a-3p-abundant small extracellular vesicles released from Gelma/nanoclay hydrogel for cartilage regeneration. J. Extracell. Vesicles 2020, 9, 1778883. [CrossRef] 
79. Tao, S.-C.; Huang, J.-Y.; Gao, Y.; Li, Z.-X.; Wei, Z.-Y.; Dawes, H.; Guo, S.-C. Small extracellular vesicles in combination with sleep-related circRNA3503: A targeted therapeutic agent with injectable thermosensitive hydrogel to prevent osteoarthritis. Bioact. Mater. 2021, 6, 4455-4469. [CrossRef]

80. Han, Q.; Xie, Q.R.; Li, F.; Cheng, Y.; Wu, T.; Zhang, Y.; Lu, X.; Wong, A.S.; Sha, J.; Xia, W. Targeted inhibition of SIRT6 via engineered exosomes impairs tumorigenesis and metastasis in prostate cancer. Theranostics 2021, 11, 6526-6541. [CrossRef]

81. Quinn, Z.; Mao, W.; Xia, Y.; John, R.; Wan, Y. Conferring receptors on recipient cells with extracellular vesicles for targeted drug delivery. Bioact. Mater. 2021, 6, 749-756. [CrossRef]

82. You, D.G.; Lim, G.T.; Kwon, S.; Um, W.; Oh, B.H.; Song, S.H.; Lee, J.; Jo, D.-G.; Cho, Y.W.; Park, J.H. Metabolically engineered stem cell-derived exosomes to regulate macrophage heterogeneity in rheumatoid arthritis. Sci. Adv. 2021, 7, eabe0083. [CrossRef] [PubMed]

83. Liang, Y.; Xu, X.; Li, X.; Xiong, J.; Li, B.; Duan, L.; Wang, D.; Xia, J. Chondrocyte-Targeted MicroRNA Delivery by Engineered Exosomes toward a Cell-Free Osteoarthritis Therapy. ACS Appl. Mater. Interfaces 2020, 12, 36938-36947. [CrossRef]

84. Xu, X.; Liang, Y.; Li, X.; Ouyang, K.; Wang, M.; Cao, T.; Li, W.; Liu, J.; Xiong, J.; Li, B.; et al. Exosome-mediated delivery of kartogenin for chondrogenesis of synovial fluid-derived mesenchymal stem cells and cartilage regeneration. Biomaterials 2021, 269, 120539. [CrossRef] [PubMed] 